\title{
Leptospirosis Fever: Case Report
}

\author{
Gajulapalle Sree lakshmi*, Gowtham M, Venkateswara Reddy L, Sireesha V and Divya G \\ Department of Pharmacy Practice, Sri Padmavathi School of Pharmacy, India
}

Submission: February 18,2019; Published: February 28, 2019

*Corresponding author: Gajulapalle Sree lakshmi, Department of Pharmacy Practice, Sri Padmavathi School of Pharmacy, Jawaharlal Nehru Technological University, Anantapuramu, Andhra Pradesh, India

\begin{abstract}
Leptospirosis is a zoonotic disease caused by infection with leptospira species which is prevalent in both tropical and temperate regions, but more common in tropics as the pathogenic bacteria survives longer in tropical environment. Leptospira species lives in kidneys of mammalian species like rodents, cattle, sheep and pig but rodents are the most common reservoir in transmission of the disease. Humans are infected incidentally after being exposed to infected animal tissue or excreta. A 47-year-old female patient admitted in our hospital in general medicine ward with chief complaints of fever for 5 days, cough for 4 days and altered sensorium for 2 days. Patient also complained about headache and involuntary passage of urine in clothes on the day of admission. Patient was a known case of asthma on oral treatment of FORACORT inhaler Patient was treated with Inj. CEFTRIAXONE, ARTESUNATE, DOXYCYCLINE, PRIMAQUINE, PARACETEMOL and IVF. Patient was discharged after complete recovery and advised to continue FORACORT for asthma.
\end{abstract}

Keywords: Zoonotic disease; Leptospira species; Pathogens; Tropical environment

\section{Introduction}

Leptospirosis is a zoonotic disease caused by infection with Leptospira species which is prevalent in both tropical and temperate regions [1], but more common in tropics as the pathogenic bacteria survives longer in tropical environment. Leptospira species lives in kidneys of mammalian species like rodents, cattle, sheep and pig but rodents are the most common reservoir in transmission of the disease. Humans are infected incidentally after being exposed to infected animal tissue or excreta [2]. Clinical features of Leptospirosis can be classified into 2 phases [3]. The first phase is known as septemic phase which is characterized by high fever, headache, myalgia, conjunctival congestion. Fever returns after a brief afebrile period indicating the second phase of illness known as immune phase in which liver and kidneys are involved. According to WHO guidelines treatment regimen for less severe cases is [4] DOXYCYCLINE, TETRACYCLINE, AMPICILLIN, AMOXICILLIN, third generation cephalosporins like CEFTRIAXONE, CEFOTAXIME and QUINOLONE antibiotics. Severe cases usually treated with high doses of BENZYLPENICILLIN (30mg/kg up to $1.2 \mathrm{~g}$ IV 6-hourly for 5-7 days). Along with antibiotics supportive care should be provided.

\section{Case Report}

A 47year old female patient admitted in our hospital in general medicine ward with chief complaints of fever for 5 days, cough for 4 days and altered sensorium for 2 days. Patient developed fever which is high grade in nature, intermittent, associated with chills, rigors and evening rise of temperature followed by cough for 4 days associated with scanty sputum production, mucoid in nature, non-foul smelling, not blood tinged followed by altered behavior for 2 days in form of increased irritability. Patient also complained about headache and involuntary passage of urine in clothes on the day of admission. She is a known case of Asthma for 5 years which aggravates on exposure to cold, associated with wheeze and subsides on oral treatment with Forecourt (FORMOTEROL FUMARATE AND BUDENOSIDE) inhaler.

\section{Diagnosis}

Physical examination and laboratory tests were performed. Report shows well defined maculopapular erythematous lesions over both upper limbs [5], blanching rash present over abdomen and chest, conjunctival congestion, terminal neck stiffness. There was no jaundice, hepatospleenomegaly, lymphadenopathy, jaundice and icterus. Laboratory results showed elevated ALT, AST and ALP with $47 \mathrm{IU} / \mathrm{L}, 58 \mathrm{IU} / \mathrm{L}$ and $192 \mathrm{IU} / \mathrm{L}$ respectively, elevated total serum bilirubin with $2.8 \mathrm{mg} / \mathrm{dl}$, reduced serum albumin with $2.4 \mathrm{mg} / \mathrm{dl}$ and conjugated serum bilirubin with $0.92 \mathrm{mg} / \mathrm{dl}$. Serological investigations of the patient by ELISA technique showed presence of IgM antibodies against Leptospira species in serum. Peripheral smear reveals no abnormalities.

\section{Treatment}

Patient was treated empirically with Inj. CEFTRIAXONE Ig IV BD. Along with ceftriaxone other symptomatic treatment was also given like Inj. ARTESUNATE (120mg IV BD), Cap. DOXYCYCLINE (100mg PO BD) and T. PARACETEMOL (500mg 
PO TID) as patient complaints of fever with chills and rigors. Inj. NEUROIND is given. Intravenous fluids like NS and RL was also given. He is using FORACORT inhaler for asthma [6,7].

\section{Outcome and Follow Up}

Patient was discharged after complete recovery and advised to continue FORACORT inhaler for Asthma. Maintain hygienic conditions in order to prevent further infections. Medication for asthma can be used whenever necessary.

\section{Discussion}

Leptospirosis is a rare zoonotic disease caused by a spirochete called leptospira which is characterized by high fever, headache, myalgia, conjunctival congestion. In our patient high grade fever, headache and rashes are observed which is supported by [5] Diagnosis is based on physical examination, signs and symptoms and also by laboratory reports which is supported by [4]. Treatment given in our patient is antibiotics and supportive care which is according to WHO guidelines.

\section{Conclusion}

Leptospirosis is a rare zoonotic disease caused by a spirochete leptospira. It is transmitted by mammalians like rodents, cattle, sheep and pigs but rodents are the most common host for leptospira species. Treatment regimen for leptospira is penicillin antibiotics, third generation cephalosporins and quinolone antibiotics. Along with the antibiotics symptomatic treatment and supportive care is also useful in many cases.

\section{References}

1. Kavinga Kalhari Kobawaka Gamage, Harshini Fernando (2018) Leptospirosis complicated with Guillain Barre syndrome, papillitis and thrombotic thrombocytopenic Purpura; a case report. Biomed Central (Venereology and Leprology): 1-2.

2. Elias Maroun, Anurag Kushawaha, Elie El Charabaty, Neville Mobarakai, Suzanne El Sayegh (2011) Fulminant Leptospirosis (Weil's disease) in an urban setting as an overlooked cause of multiorgan failure: a case report. J Med Case Rep 5: 7.

3. Bal Abhijit M (2005) Unusual clinical manifestations of leptospirosis. J Postgrad Med 51(3): 179-83.

4. Monika Jawanjal, Smita Patil, Manish Pendse, Archana Bhate, Shariq Hooda (2014) An Unusual Presentation of Leptospirosis: A Case Report. Open Journal of Clinical Diagnostics 4(2): 112-116.

5. Sainte Marie, Delord M, Dubourg G, Gautret P, Parola P, et al. (2015) Leptospirosis presenting as honeymoon fever. International Journal of Infectious Diseases 34: 102-104.

6. Tomari K, Toyokawa T, Takahashi T, Kakita T, Okano S, et al. (2018) Childhood leptospirosis in an industrialized country: Population-based study in Okinawa, Japan. PLoS Negl Trop Dis 12(3): e0006294.

7. Swamikannu Murugan, Muhammed Zohaib Ghatala, Anand Sankar S, Jothi Krishnan (2014) Atypical Presentation of Multiorgan Failure Leptospirosis (Weil's Disease) without Fever. Indian Journal of Clinical Practice 24(10): 948-951.

\section{Your next submission with Juniper Publishers will reach you the below assets}

- Quality Editorial service

- Swift Peer Review

- Reprints availability

- E-prints Service

- Manuscript Podcast for convenient understanding

- Global attainment for your research

- Manuscript accessibility in different formats ( Pdf, E-pub, Full Text, Audio)

- Unceasing customer service

Track the below URL for one-step submission https://juniperpublishers.com/online-submission.php 